\title{
Investigation of celiac disease followed by immune thrombocytopenic purpura diagnosis in patients and comparison with literature
}

\author{
Hakan Sarbay, ${ }^{1}$ Halil Kocamaz, ${ }^{2}$ Mehmet Akin, ${ }^{1}$ Bayram Ozhan ${ }^{3}$ \\ ${ }^{1}$ Department of Pediatric Hematology and Oncology, Pamukkale University Faculty of Medicine, Denizli, Turkey \\ 2Department of Pediatric Gastroenterology, Pamukkale University Faculty of Medicine, Denizli, Turkey \\ ${ }^{3}$ Department of Pediatric Endocrinology, Pamukkale University Faculty of Medicine, Denizli, Turkey
}

\begin{abstract}
OBJECTIVE: Celiac disease (CD) and Immune thrombocytopenic purpura (ITP) may occur together as a result of similar autoimmune mechanisms. The aim of this study was to assess the frequency of $\mathrm{CD}$ in a group of ITP patients and in the literature.
\end{abstract}

METHODS: A total of 29 patients in Pamukkale University Faculty of Medicine Hospital Pediatric Hematology and Oncology Department with ITP were included in the study. Test was performed for the antibodies related to CD. Positive result for celiac antibodies was confirmed with biopsy. The results were compared with the literature.

RESULTS: Of the study group, 13 patients (44.8\%) were female and 16 (55.2\%) were male. The mean age was $7.2 \pm 4.7$ years and mean platelet count at the time of admission was $13,440 \pm 11,110 / \mathrm{mm}^{3}$ (range: $2000-41,000$ / $\left.\mathrm{mm}^{3}\right)$. Twelve patients (41.4\%) were diagnosed as acute ITP, 6 patients (20.7\%) as persistent ITP, and 11 patients (37.9\%) as chronic ITP, according to the duration of thrombocytopenia. Antibody positivity was detected in 1 patient. Histological evaluation was compatible with $C D$. Results were compared with studies regarding the prevalence of $C D$ in the population. No significant difference was found.

CONCLUSION: Although it is not necessary to perform CD test in every case of ITP, the presence of differential diagnosis of $C D$ is important to prevent unnecessary treatment, especially in ITP patients with growth retardation or malabsorption findings.

Keywords: Autoimmunity; celiac disease; immune thrombocytopenic purpura.

$I^{\prime}$ mmune thrombocytopenic purpura (ITP) is the most frequent cause of sudden onset thrombocytopenia in healthy children. In children, it usually emerges after an infection or a vaccination. It is an acquired disease, coursing with thrombocytopenia developing as an outcome of a decrease in the lifespan of platelets caused by autoantibodies formed against platelets $[1,2]$.

Received: January 13, 2017 Accepted: April 19, 2017 Online: August 26, 2017

Correspondence: Dr. Hakan SARBAY. Pamukkale Universitesi Tip Fakultesi, Cocuk Hematoloji

ve Onkoloji Bilim Dali, Denizli, Turkey.

Tel: +90 258 - 2966000 e-mail: drhakansarbay@hotmail.com

(c) Copyright 2017 by Istanbul Northern Anatolian Association of Public Hospitals - Available online at www.kuzeyklinikleri.com 
Celiac disease (CD) is an immunological disease induced by intolerance of the small bowel to gluten. Growth retardation and chronic diarrhea are the most frequently seen manifestations [3]. In addition to the typical findings of malabsorption, many autoimmunological disorders may accompany the disease, or there may be extraintestinal findings, such as growth retardation, developmental delay, impaired hepatic function, skin manifestations, osteoporosis, or hematological disorders $[4,5]$. As a result of having similar autoimmune mechanisms, in some publications, $\mathrm{CD}$ has been reported as a risk factor for ITP [6]. The aim of this article was to evaluate the frequency of CD in a group of patients and compare the results with literature data.

\section{MATERIALS AND METHODS}

A total of 29 patients with a diagnosis of ITP whose follow-up and treatment were ongoing at the Department of Pediatric Hematology and Oncology of the Pamukkale University Faculty of Medicine were included in the study. CD manifestations, and anti-endomysial antibody (EMA), tissue transglutaminase antibody ( $\mathrm{tTG}$ ), and immunoglobulin A (IgA) levels were evaluated. Age, gender, platelet count at the time of admission, and duration of thrombocytopenia were recorded. Based on the duration of the disease, thrombocytopenia was classified as acute ( $<3$ months), persistent (3-12 months), or chronic (>12 months) thrombocytopenia. EMA and tTG positivity was confirmed with endoscopic examination and histological analyses. The results were compared with literature data. The study was approved by the ethics committee of Pamukkale University (2017/01-10.01.17). Written, informed consent was obtained from the parents of all patients.

\section{Statistical analyses}

All descriptive statistical analyses were performed using IBM SPSS Statistics for Windows, Version 22.0 (IBM Corp., Armonk, NY, USA). Fisher chisquare test was used for the comparison of categorical variables.

\section{RESULTS}

Thirteen female (44.8\%) and 16 male (55.2\%) patients with a collective mean age of $7.2 \pm 4.7$ years (range: 7 months -17 years) were included in the study. Mean platelet count at admission was $13,440 \pm 11,110 / \mathrm{mm}^{3}$ (range: $2000-$ $41,000 \mathrm{~mm}^{3}$ ). The type of ITP was classified based on the duration of thrombocytopenia as acute $(n=12 ; 41.4 \%)$, persistent $(n=6 ; 20.7 \%)$, or chronic $(n=11 ; 37.9 \%)$. Clinical and laboratory characteristics of the patients are provided in Table 1.

Examination for the presence of $C D$ revealed tTG $\operatorname{IgA}: 24.1 \mathrm{U} / \mathrm{mL}(<20 \mathrm{U} / \mathrm{mL})$ and EMA positivity in 1 patient, a 9-year-old female with weight of $22 \mathrm{~kg}$ (3-10 percentile) and height of $118 \mathrm{~cm}$ (<3 percentile). Some notable laboratory parameters were as follows; white blood cell count: $6360 / \mathrm{mm}^{3}$, hemoglobin: $11.4 \mathrm{~g} / \mathrm{dL}$, platelet count: $28,000 / \mathrm{mm}^{3}$, aspartate aminotransferase: $174 \mathrm{IU} / \mathrm{L}$, alanine aminotransferase: $193 \mathrm{IU} / \mathrm{L}$, lactate dehydrogenase: $914 \mathrm{U} / \mathrm{L}$, ferritin: $42 \mathrm{ng} /$ $\mathrm{mL}$, iron: $38 \mathrm{ug} / \mathrm{dL}$, total iron binding capacity: $300 \mathrm{ug} / \mathrm{dL}$, vitamin B12: $284 \mathrm{pg} / \mathrm{mL}$, folate: 9.9 $\mathrm{ng} / \mathrm{mL}$, prothrombin time: 12.1 seconds, partial thromboplastin time: 28 seconds, international normalized ratio 1.08 , free thyroxine $1.39 \mathrm{ng} / \mathrm{dL}$, and thyroid stimulating hormone: $3.21 \mathrm{uIU} / \mathrm{mL}$. In addition to thrombocytopenia, the patient had impaired liver function and growth retardation. On peripheral smear, no atypical cells or blast cells were seen, and an average of 2 platelets were noted in every microscopic field of view. Histopathological examination of bone marrow aspiration biopsy specimen revealed an increase in the number of immature-mature megakaryocytes without any blast cells. The patient underwent endoscopic biopsy with the initial diagnosis of CD, and histopathological analysis revealed the presence of severe mucosal injury, villous atrophy, increase in the number of intraepithelial lymphocytes, and cryptic hyperplasia (Figure 1). Histopathological diagnosis was reported as consistent with Stage $3 c$ CD based on modified Marsh classification. No treatment was administered due to the lack of 
TABLE 1. Characteristic features of the study participants

\begin{tabular}{|c|c|c|c|c|c|c|c|}
\hline $\begin{array}{l}\text { Patient } \\
\text { no. }\end{array}$ & Gender & Age & $\begin{array}{l}\text { Platelet count } \\
\qquad\left(/ \mathrm{mm}^{3}\right)\end{array}$ & $\begin{array}{l}\text { Duration of } \\
\text { thrombocytopenia }\end{array}$ & $\begin{array}{c}\text { tTG Ig A level } \\
(\mathrm{U} / \mathrm{mL})\end{array}$ & $\begin{array}{c}\text { Ig A level } \\
\text { (mg/dL) }\end{array}$ & Type \\
\hline 1 & Female & 9 years & 28,000 & 5 months & 24.2 & 420 & Persistent \\
\hline 2 & Female & 15 years & 11,000 & 1 month & 2.94 & 48 & Acute \\
\hline 3 & Female & 8 years & 31,000 & 17 months & 5.2 & 301 & Chronic \\
\hline 4 & Female & 9 years & 7000 & 2 months & 1.19 & 74 & Acute \\
\hline 5 & Male & 4 years & 1000 & 1 month & 0.99 & 38 & Acute \\
\hline 6 & Male & 7 months & 16,000 & 6 months & 0.96 & 36 & Persistent \\
\hline 7 & Male & 2 years & 24,000 & 1 month & 0.45 & 42 & Acute \\
\hline 8 & Male & 4 years & 25,000 & 1 month & 1.66 & 44 & Acute \\
\hline 9 & Male & 10 years & 20,000 & 6 months & 0.74 & 90 & Persistent \\
\hline 10 & Female & 6 years & 21,000 & 1 month & 0.65 & 106 & Acute \\
\hline 11 & Male & 16 years & 2000 & 18 months & 0.89 & 148 & Chronic \\
\hline 12 & Male & 3 years & 3000 & 1 month & 1.13 & 149 & Acute \\
\hline 13 & Male & 4 years & 9000 & 8 months & 3.1 & 47 & Persistent \\
\hline 14 & Male & 10 years & 15,000 & 3 years & 1.69 & 253 & Chronic \\
\hline 15 & Male & 1 year & 11,000 & 1 year & 0.89 & 86 & Chronic \\
\hline 16 & Female & 15 years & 2000 & 1 month & 2.06 & 71 & Acute \\
\hline 17 & Female & 9 years & 9000 & 2 years & 1.04 & 105 & Chronic \\
\hline 18 & Female & 5 years & 3000 & 1 month & 2.1 & 162 & Acute \\
\hline 19 & Male & 3 years & 4000 & 4 years & 1.72 & 67 & Chronic \\
\hline 20 & Female & 8 months & 41,000 & 18 months & 3.2 & 72 & Chronic \\
\hline 21 & Female & 6 years & 2000 & 6 months & 1.39 & 168 & Persistent \\
\hline 22 & Female & 9 years & 29,000 & 6 months & 1.55 & 80 & Persistent \\
\hline 23 & Female & 10 years & 15,000 & 1 month & 4.44 & 142 & Acute \\
\hline 24 & Male & 17 years & 29,000 & 5 years & 3.12 & 99 & Chronic \\
\hline 25 & Female & 7 years & 4000 & 2 years & 4.97 & 93 & Chronic \\
\hline 26 & Male & 3 years & 15,000 & 1 month & 2.17 & 33 & Acute \\
\hline 27 & Male & 4 years & 1000 & 2 months & 3 & 138 & Acute \\
\hline 28 & Male & 8 years & 2000 & 4 years & 1.39 & 217 & Chronic \\
\hline 29 & Male & 12 years & 10,000 & 18 months & 1.2 & 113 & Chronic \\
\hline
\end{tabular}

Ig A: Immunoglobulin A; tTG: tissue transglutaminase.

any finding of active bleeding and platelet count greater than $10,000 / \mathrm{mm}^{3}$. The patient was started on a gluten-free diet. One month later, platelet count had risen to $87,000 / \mathrm{mm}^{3}$. At fifth month of dietary therapy, platelet count of the patient was within normal limits.

In our study, the frequency of CD observed in our ITP patients was not significantly different from the results of previously performed studies related to the incidence of CD (Table 2).

\section{DISCUSSION}

In cases of $\mathrm{CD}$, generally, the clinical findings become manifest due to intestinal mucosa injury and resultant malabsorption [7]. As a result of deficient intestinal absorption, and as an autoimmune disease, various hematological symptoms can be seen in CD. Treatment-resistant iron deficiency is the most frequently seen hematological disorder seen in atypical $\mathrm{CD}[7,8]$. In addition to iron deficiency, 


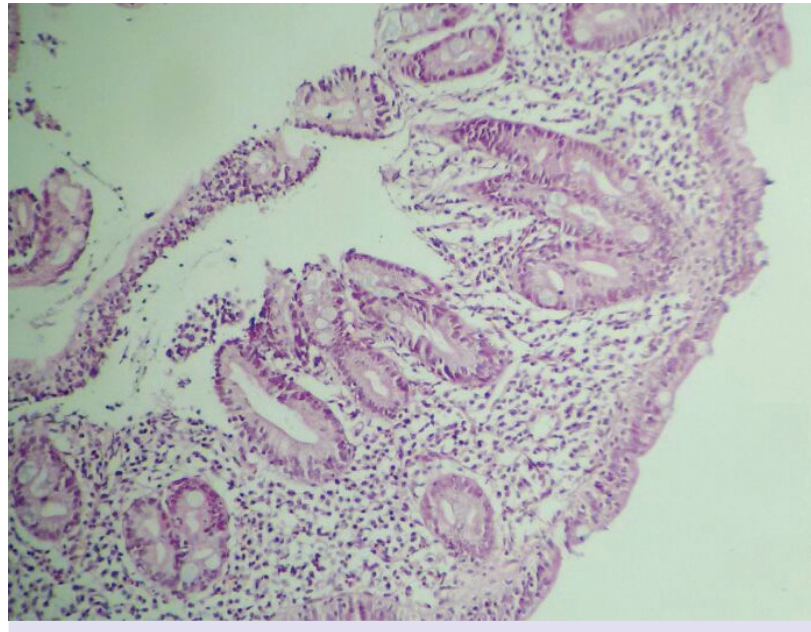

FIGURE 1. Histopathological examination of the biopsy material of the patients revealed villous atrophy, increase in the intraepithelial number of lymphocytes, and cryptic hyperplasia.

folic acid, and vitamin B12 deficiencies may be also seen [7]. In a study performed in our country, 21 of 22 patients diagnosed as $C D$, iron deficiency anemia was detected. Among them, 7 also had vitamin B12 deficiency, and folic acid deficiency was observed in 1 patient [9]. In CD, apart from anemia, leukopenia and thrombocytopenia may develop due to vitamin B12 and folic acid deficiencies, and immune cytopenias, such as ITP, can develop via different autoimmune mechanisms [8].

Concomitancy between CD and ITP was first described in 1988, and studies performed have demonstrated the presence of similar autoimmune mechanisms in the pathogenesis of both diseases [10]. It has been determined that the native immune system is important in the pathogenesis of $\mathrm{CD}$, and that toll-like receptors (TLRs) also play a key role [11]. Zanoni et al. [12] demonstrated that in some cases of CD, tTG antibodies induce TLR4 activation. Presumably, TLR4 expression in platelets leads to thrombocytopenia [13].

$\mathrm{CD}$ is a frequently seen disease in the community; however, diagnosis can be overlooked due to its multivariant symptoms [14]. In a study performed in our country that screened 20,190 children, CD prevalence was detected at $0.47 \%$ [15]. Demirçeken et al. performed a study of tTG antibodies among healthy children aged 2 to 18 years who presented at the hospital, and found a prevalence of CD of $1 \%$ [16]. In another study performed in Turkey, CD was detected in 11 of 1263 children [17]. Cilleruelo et al. [18] evaluated 1291 newborns, and antibody positivity was found in 19 cases; 15 were diagnosed as CD based on histopathological evaluation of biopsy specimen. Prevalence of CD was found to be $1.1 \%$. As an outcome of our study, among 29 ITP patients, antibody positivity and histopathological diagnosis of CD was detected in 1 patient. A significant difference was not found when our results were compared with literature data.

In cases of ITP associated with CD cited in the literature, an increase in platelet count to normal limit within an average of 1 year was observed with gluten-free diet and without the need for intravenous immunoglobulin or steroid treatment [19].

TABLE 1. Comparison of our results with results of other studies

\begin{tabular}{lccccc} 
& $\begin{array}{c}\text { Number of } \\
\text { patients with CD }\end{array}$ & $\begin{array}{c}\text { Number of } \\
\text { patients without CD }\end{array}$ & $\begin{array}{c}\text { Total number } \\
\text { of patients }\end{array}$ & $\begin{array}{c}\text { Frequency } \\
\%\end{array}$ & $p$ \\
\hline Present study & 1 & 28 & 29 & 3.4 & \\
Dalgıç et al. & 95 & 20,095 & 20,190 & 0.5 & $\mathrm{p}=0.129$ \\
Demirçeken et al. & 10 & 990 & 1000 & 1 & $\mathrm{p}=0.271$ \\
Ertekin et al. & 11 & 1252 & 1263 & 0.8 & $\mathrm{p}=0.239$ \\
Cilleruelo et al. & 15 & 1276 & 1291 & 1.1 & $\mathrm{p}=0.301$ \\
\hline
\end{tabular}

$\mathrm{p}<0.05$ significant; CD: Celiac disease. 
In our patient, platelet count 1 month after initiation of gluten-free diet was $87,000 / \mathrm{mm}^{3}$, and at 5 months, value was normal.

In conclusion, ITP is one of the atypical findings of $\mathrm{CD}$ that may accompany $\mathrm{CD}$ due to a similar autoimmunme mechanism. Although investigation for $\mathrm{CD}$ is not required in every case diagnosed as ITP, in ITP patients with developmental retardation or malabsorption, considering $\mathrm{CD}$ in the differential diagnosis is important so as to prevent unnecessary treatment.

Conflict of Interest: None declared.

Financial Disclosure: The authors declared that this study has received no financial support.

Authorship contributions: Concept - H.S.; Design - H.S.; Supervision - H.S., H.K., M.A., B.O.; Materials - H.S.; Data collection \&/or processing - H.S.; Analysis and/or interpretation - H.S.; Literature search - H.S.; Writing - H.S.; Critical review - H.S., H.K., M.A., B.O.

\section{REFERENCES}

1. Celkan T. Changes in chilhood ITP treatment and follow-up in 2011. Turk Pediatri Ars 2012;47:8-17.

2. Bussel J. Disorders of platelets. In: Lanzkowsky P, editor. Manual of pediatric hematology and oncology. 5th ed. San Diego: Elsevier Academic Press; 2011: 321-77.

3. Hill ID, Dirks MH, Liptak GS, Colletti RB, Fasano A, Guandalini S, North American Society for Pediatric Gastroenterology, Hepatology and Nutrition. Guideline for the diagnosis and treatment of celiac disease in children: recommendations of the North American Society for Pediatric Gastroenterology, Hepatology and Nutrition. J Pediatr Gastroenterol Nutr 2005;40:1-19.

4. Mehta G, Taslaq S, Littleford S, Bansi DS, Thillainayagam A. The changing face of coeliac disease. Br J Hosp Med (Lond) 2008;69:84-7.

5. Cataldo F, Marino V. Increased prevalence of autoimmune diseases in first-degree relatives of patients with celiac disease. J Pediatr Gastroenterol Nutr 2003;36:470-3.

6. Lauret E, Rodrigo L. Celiac disease and autoimmune-associated conditions. Biomed Res Int 2013;2013:127589.

7. Fasano A. Clinical presentation of celiac disease in the pediatric population. Gastroenterology 2005;128:S68-73.

8. Halfdanarson TR, Litzow MR, Murray JA. Hematologic manifestations of celiac disease. Blood 2007;109:412-21.

9. Fisgin T, Yarali N, Duru F, Usta B, Kara A. Hematologic manifestation of childhood celiac disease. Acta Haematol 2004;111:211-4.

10. Olén O, Montgomery SM, Elinder G, Ekbom A, Ludvigsson JF. Increased risk of immune thrombocytopenic purpura among inpatients with coeliac disease. Scand J Gastroenterol 2008;43:416-22.

11. Stepniak D, Koning F. Celiac disease-sandwiched between innate and adaptive immunity. Hum Immunol 2006;67:460-8.

12. Zanoni G, Navone R, Lunardi C, Tridente G, Bason C, Sivori S, et al. In celiac disease, a subset of autoantibodies against transglutaminase binds toll-like receptor 4 and induces activation of monocytes. PLoS Med 2006;3:e358.

13. Aslam R, Speck ER, Kim M, Crow AR, Bang KW, Nestel FP, et al. Platelet Toll-like receptor expression modulates lipopolysaccharide-induced thrombocytopenia and tumor necrosis factoralpha production in vivo. Blood 2006;107:637-41.

14. Biagi F, Klersy C, Balduzzi D, Corazza GR. Are we not overestimating the prevalence of coeliac disease in the general population? Ann Med 2010;42:557-61.

15. Dalgic B, Sari S, Basturk B, Ensari A, Egritas O, Bukulmez A, et al; Turkish Celiac Study Group. Prevalence of celiac disease in healthy Turkish school children. Am J Gastroenterol 2011;106:1512-7.

16. Demirçeken FG, Kansu A, Kuloğlu Z, Girgin N, Güriz H, Ensari A. Human tissue transglutaminase antibody screening by immunochromatographic line immunoassay for early diagnosis of celiac disease in Turkish children. Turk J Gastroenterol 2008;19:14-21.

17. Ertekin V, Selimoğlu MA, Kardaş F, Aktaş E. Prevalence of celiac disease in Turkish children. J Clin Gastroenterol 2005;39:68991.

18. Cilleruelo ML, Fernández-Fernández S, Jiménez-Jiménez J, Rayo AI, de Larramendi CH. Prevalence and Natural History of Celiac Disease in a Cohort of At-risk Children. J Pediatr Gastroenterol Nutr 2016;62:739-45.

19. Hammami S, Hadded S, Lajmi K, Besbès LG, Meriem CB, Chouchane $\mathrm{S}$, et al. Immune thrombocytopenic purpure and coeliac disease. J Paediatr Child Health 2011;47:240. 